\title{
Measuring Tibial Forces is More Useful than Varus-Valgus Laxities for Identifying and Correcting Overstuffing in Kinematically Aligned Total Knee Arthroplasty
}

Joshua D. Roth, $\mathrm{PhD}^{1,2,3}$, Stephen M. Howell, $\mathrm{MD}^{4}$, Maury L. Hull, $\mathrm{PhD}^{4,5,6}$

${ }^{1}$ Department of Orthopedics and Rehabilitation, University of Wisconsin-Madison

${ }^{2}$ Department of Mechanical Engineering, University of Wisconsin-Madison

${ }^{3}$ Biomedical Engineering Graduate Group, University of California, Davis

${ }^{4}$ Department of Biomedical Engineering, University of California, Davis

${ }^{5}$ Department of Mechanical Engineering, University of California, Davis

${ }^{6}$ Department of Orthopaedic Surgery, University of California, Davis

Corresponding Author:

Joshua D. Roth, $\mathrm{PhD}$

telephone: +1 608-265-4086

fax: +1 608-262-2989

email: roth@ortho.wisc.edu

Running Title: Correcting Overstuffing in KA TKA

Author Contributions Statement: All authors made substantial contributions to research design, or the acquisition, analysis or interpretation of data. All authors made substantial contributions to drafting the paper or revising it critically All authors have read and approved the final submitted manuscript. 
medRxiv preprint doi: https://doi.org/10.1101/19013755; this version posted December 5, 2019. The copyright holder for this preprint (which was not certified by peer review) is the author/funder, who has granted medRxiv a license to display the preprint in perpetuity.

It is made available under a CC-BY-NC-ND 4.0 International license .

\section{Abstract}

2 Identifying and correcting varus-valgus $(\mathrm{V}-\mathrm{V})$ malalignment of the tibial component is important when

3 balancing a kinematically aligned total knee arthroplasty (TKA). Accordingly, the primary objective

4 was to determine whether the tibial forces or V-V laxities are more sensitive to, and thus more useful

5 for identifying and correcting, V-V malalignments of the tibial component that overstuff a

6 compartment. Calipered kinematically aligned TKA was performed on nine human cadaveric knees.

7 Medial and lateral tibial forces and V-V laxities were measured from $0^{\circ}$ to $120^{\circ}$ flexion with an

8 unmodified reference tibial component and modified tibial components that introduced $\pm 1^{\circ}$ and $\pm 2^{\circ} \mathrm{V}$ -

9 V malalignments from the reference component to overstuff either the medial or lateral compartment.

10 Changes in the tibial forces were most sensitive to V-V malalignments at $0^{\circ}$ flexion (medial $=118 \pm 34$

$11 \mathrm{~N} / \mathrm{deg}$ valgus malalignment and lateral $=79 \pm 20 \mathrm{~N} / \mathrm{deg}$ varus malalignment). The varus and valgus

12 laxities were most sensitive to $\mathrm{V}-\mathrm{V}$ malalignments at $30^{\circ}$ flexion $(-0.6 \pm 0.1 \mathrm{deg} / \mathrm{deg}$ varus

13 malalignment) and $120^{\circ}$ flexion (-0.4 $\pm 0.2 \mathrm{deg} / \mathrm{deg}$ valgus malalignment), respectively. The maximum

14 average signal-to-noise ratios of the sensitivities to changes in tibial forces and V-V laxities were 8.4

$15 \mathrm{deg}^{-1}$ and $0.9 \mathrm{deg}^{-1}$, respectively, based on reported measurement errors (i.e., noise) using current

16 intraoperative technologies $\left(14 \mathrm{~N}\right.$ and $\left.0.7^{\circ}\right)$. Because of the greater signal-to-noise ratios, measuring

17 tibial forces is more useful than V-V laxities for identifying and correcting V-V malalignments of the

18 tibial component that overstuff a compartment. Clinical Significance: The sensitivities of tibial forces

19 provide objective guidance to surgeons performing V-V recuts of the tibia.

21 Key Words: Total knee replacement, contact force, component alignment, component malrotation, 22 soft tissue balance 
medRxiv preprint doi: https://doi.org/10.1101/19013755; this version posted December 5, 2019. The copyright holder for this preprint (which was not certified by peer review) is the author/funder, who has granted medRxiv a license to display the preprint in perpetuity.

It is made available under a CC-BY-NC-ND 4.0 International license .

\section{Introduction}

The surgical alignment goal of kinematically aligned total knee arthroplasty (TKA) is to restore

the native joint lines with the ultimate functional goal of restoring knee function to native. Restoration

27 of the joint lines, in turn, closely restores the native alignments of the limb and knee and eliminates the

28 need for ligament releases ${ }^{1,2}$. Kinematically aligning the femoral component is relatively straight

29 forward because the resection thicknesses can be measured using calipers (i.e., calipered kinematic

30 alignment $^{3}$ ). However, kinematically aligning the tibial component is more challenging because the

31 resection plane must be correctly aligned in both the coronal and sagittal planes. The combination of

32 irregular geometry of the tibial articular surface ${ }^{4}$ and large amounts of cartilage and bone wear ${ }^{5}$ further

33 complicates the task of achieving correct alignment of the tibial resection plane.

34 In calipered kinematically aligned TKA, the varus-valgus (V-V) orientation of the tibial

35 resection is adjusted to balance medial and lateral soft tissues. The current intraoperative verification

36 check for proper $\mathrm{V}-\mathrm{V}$ alignment of the tibial component is that the knee is stable in extension based on

37 a manual V-V laxity assessment by the surgeon ${ }^{6}$. However, because identifying an overly tight (i.e.,

38 overstuffed) knee by manually checking laxities is challenging ${ }^{7}$, it is important to consider more

39 accurate intraoperative technologies such as computer navigation for measuring laxities ${ }^{8}$ and sensors

40 for measuring tibial forces ${ }^{9,10}$. The utility of these two technologies can be compared based on their

41 signal-to-noise ratios. The 'signal' is the sensitivity of changes in the laxities/tibial forces due to V-V

42 malalignment of the tibial component that overstuffs a compartment of the tibiofemoral joint. The

43 'noise' is the error in measuring the laxities/tibial forces using current intraoperative technologies.

44 Thus, the better of the two technologies for detecting V-V malalignments of the tibial component

45 would have a higher signal-to-noise ratio. Further, the sensitivities of changes in the better variable

46 would indicate to the surgeon the amount of adjustment necessary in the $\mathrm{V}-\mathrm{V}$ orientation of the tibial 
medRxiv preprint doi: https://doi.org/10.1101/19013755; this version posted December 5, 2019. The copyright holder for this preprint (which was not certified by peer review) is the author/funder, who has granted medRxiv a license to display the preprint in perpetuity.

It is made available under a CC-BY-NC-ND 4.0 International license .

resection to realize a desired change in laxity or change in tibial force to achieve the desired soft tissue balance.

Prior studies have indicated that changes in the tibial forces are sensitive to small V-V malalignments of the tibial component in mechanically aligned $\mathrm{TKA}^{11}$. However, because there are fundamental differences between the surgical alignment goals and surgical techniques to achieve the surgical alignment goals between mechanically and kinematically aligned TKA ${ }^{12}$, it is important to determine the sensitivity in changes in both the laxities and tibial forces to $\mathrm{V}-\mathrm{V}$ malalignments of the tibial component in kinematically aligned TKA. Additionally, because prior studies have shown wide variability in both the tibial forces ${ }^{13}$ and laxities ${ }^{14}$ from knee to knee, it is important to determine how much these sensitivities vary from knee to knee. If the sensitivities vary widely, then it might not be feasible to determine the amount of correction for an individual patient based on a mean value. Accordingly, there were three objectives. The first objective was to determine the sensitivities of the tibial forces and $\mathrm{V}-\mathrm{V}$ laxities to $\mathrm{V}-\mathrm{V}$ malalignments of the tibial component that overstuff a compartment. By comparing signal-to-noise ratios for $\mathrm{V}-\mathrm{V}$ laxities and tibial forces based on sensitivities and errors using currently available technologies ${ }^{15,16}$, the second objective was to determine whether the changes in laxities or tibial forces are more useful for identifying and correcting $\mathrm{V}-\mathrm{V}$ malalignments of the tibial component that overstuff a compartment. The third objective was to determine whether the variability in sensitivities from knee to knee was sufficiently low so that the amount of correction for an individual could be based on the mean value of the sensitivity.

\section{Methods}

$$
\text { Nine fresh-frozen human cadaveric knees (average age }=74 \text { years, range }=57 \text { to } 93 \text { years, } 6
$$
males) were included. With nine knees, strong relationships between $\mathrm{V}-\mathrm{V}$ malalignments of the tibial component and tibial forces/laxities (i.e., $\left.r^{2}>0.55\right)$ could be detected with $\alpha=0.05$ and $(1-\beta)=0.8^{17}$.

Each knee was free of radiographic signs of degenerative joint disease (i.e., marginal osteophytes, joint 
medRxiv preprint doi: https://doi.org/10.1101/19013755; this version posted December 5, 2019. The copyright holder for this preprint (which was not certified by peer review) is the author/funder, who has granted medRxiv a license to display the preprint in perpetuity.

It is made available under a CC-BY-NC-ND 4.0 International license .

space narrowing, chondrocalcinosis, and/or subchondral sclerosis) and evidence of previous surgery to the knee.

After thawing overnight, each native knee specimen was dissected and aligned in a six degreeof-freedom load application system ${ }^{18}$ in preparation for measuring the tibial forces and laxities using previously described protocols ${ }^{14,19-22}$. Briefly, to enable the application of muscle forces, cloth loops

were sutured to the tendons of insertion of the quadriceps, the biceps femoris, and the

semimembranosus and semitendinosus (sutured together due to shared line of action $^{23}$ ). Subsequent to a functional alignment procedure ${ }^{14,19}$, the shafts of the femur and tibia were cemented within square aluminum tubes using methyl methacrylate (COE Tray Plastic, GC America Inc., Alsip, IL) to rigidly fix the position and orientation of the knee specimen relative to the load application system and enable removal and reinsertion of the knee specimen during subsequent testing in the load application system $^{18}$. Before determining the full extension position of each knee (i.e., $0^{\circ}$ flexion), each knee specimen was subjected to a preconditioning protocol consisting of first cycling five times between \pm $2.5 \mathrm{Nm}$ in flexion-extension $(\mathrm{F}-\mathrm{E})$ and then extending under $2.5 \mathrm{Nm}$ to define $0^{\circ}$ flexion ${ }^{24}$. Kinematically aligned TKA was performed using cruciate-retaining components (Persona CR, Zimmer Biomet, Inc, Warsaw, IN, USA) and disposable manual instruments without ligament release following a previously described technique ${ }^{3,25}$. Briefly, the knee was exposed through a mid-sagittal osteotomy of the patella ${ }^{26}$. The goal of maintaining the native the distal and posterior femoral joint lines was accomplished by matching the thicknesses of the distal medial, distal lateral, posterior medial, and posterior lateral femoral resections to within $0.5 \mathrm{~mm}$ as measured using calipers to the corresponding condylar regions of the femoral component after correcting for the kerf of the saw 92 blade $^{25}$.

Next a conservative tibial resection was performed with the $\mathrm{V}-\mathrm{V}$ orientation and posterior slope set visually by the surgeon to match the those of the native tibial plateau. After inserting trial 
medRxiv preprint doi: https://doi.org/10.1101/19013755; this version posted December 5, 2019. The copyright holder for this preprint (which was not certified by peer review) is the author/funder, who has granted medRxiv a license to display the preprint in perpetuity.

It is made available under a CC-BY-NC-ND 4.0 International license .

laxity at $0^{\circ}$ flexion as judged visually by the surgeon ${ }^{19,25}$. The posterior slope of the tibial resection was also adjusted via re-cuts until the anterior-posterior (A-P) offset (i.e., distance between the distal medial femoral condyle and the anterior cortex of the tibia) measured with a caliper at $90^{\circ}$ flexion matched that of the knee at the time of exposure ${ }^{25}$. These checks have been shown to result in a V-V orientation of the tibial component within $0.0^{\circ} \pm 1.8^{\circ}$ of that of the contralateral healthy knee ${ }^{2}$ and a posterior slope within $-0.2^{\circ} \pm 2.5^{\circ}$ of the pre-operative posterior slope ${ }^{1}$. The internal-external (I-E) rotation of the tibial component was set parallel to the F-E plane of the knee, which is the plane in which the tibia flexes and extends, using templates that have been shown to align the A-P axis of the tibial component with a root mean squared error of $4^{\circ}$ from the F-E plane of the knee ${ }^{27}$.

After the correctly sized trial components were determined and properly aligned based on the previously described verification checks, the femoral component was coated with petroleum jelly and cemented to the distal femur. The tibial baseplate was coated with petroleum jelly and cemented into the proximal tibia after which the correctly sized tibial insert was attached. The petroleum jelly allowed the components to be released from the cement mantles, which enabled accurate exchanges of tibial components and the tibial force sensor described below. After the cement cured, the components were removed. The patella was not resurfaced.

Varus-valgus malalignment of the tibial component was created by modifying both a commercially available tibial baseplate (Persona CR, Zimmer Biomet, Inc.) for use while measuring the laxities and the articular surface inserts of the custom tibial force sensor ${ }^{21}$ for use while measuring the tibial forces (Figure 1). These modifications were performed using 3D modeling software (SolidWorks 2014, Dassault Systèmes). To create malalignments that would be correctable by a V-V re-cut, varus malalignments were made about the medial edge of the tibial baseplate, and valgus malalignments were made about the lateral edge of the tibial baseplate. Thus, varus malalignments primarily overstuffed the lateral compartment, and valgus malalignments primarily overstuffed the medial compartment (Figure 1). Five tibial baseplates and five sets of articular surface inserts were 3D 
medRxiv preprint doi: https://doi.org/10.1101/19013755; this version posted December 5, 2019. The copyright holder for this preprint (which was not certified by peer review) is the author/funder, who has granted medRxiv a license to display the preprint in perpetuity.

It is made available under a CC-BY-NC-ND 4.0 International license .

121 printed (Gray60, Objet Eden260VS, Stratasys, Ltd.) for each tibial baseplate size (four with modified

122 geometry to create malalignments of $1^{\circ}$ varus, $2^{\circ}$ varus, $1^{\circ}$ valgus, and $2^{\circ}$ valgus and one $0^{\circ}$ reference

123 baseplate/set of articular surface inserts with unmodified geometry). Values of $1^{\circ}$ and $2^{\circ}$ were selected

124 to span the malalignments correctable with $2^{\circ}$ re-cut guides.

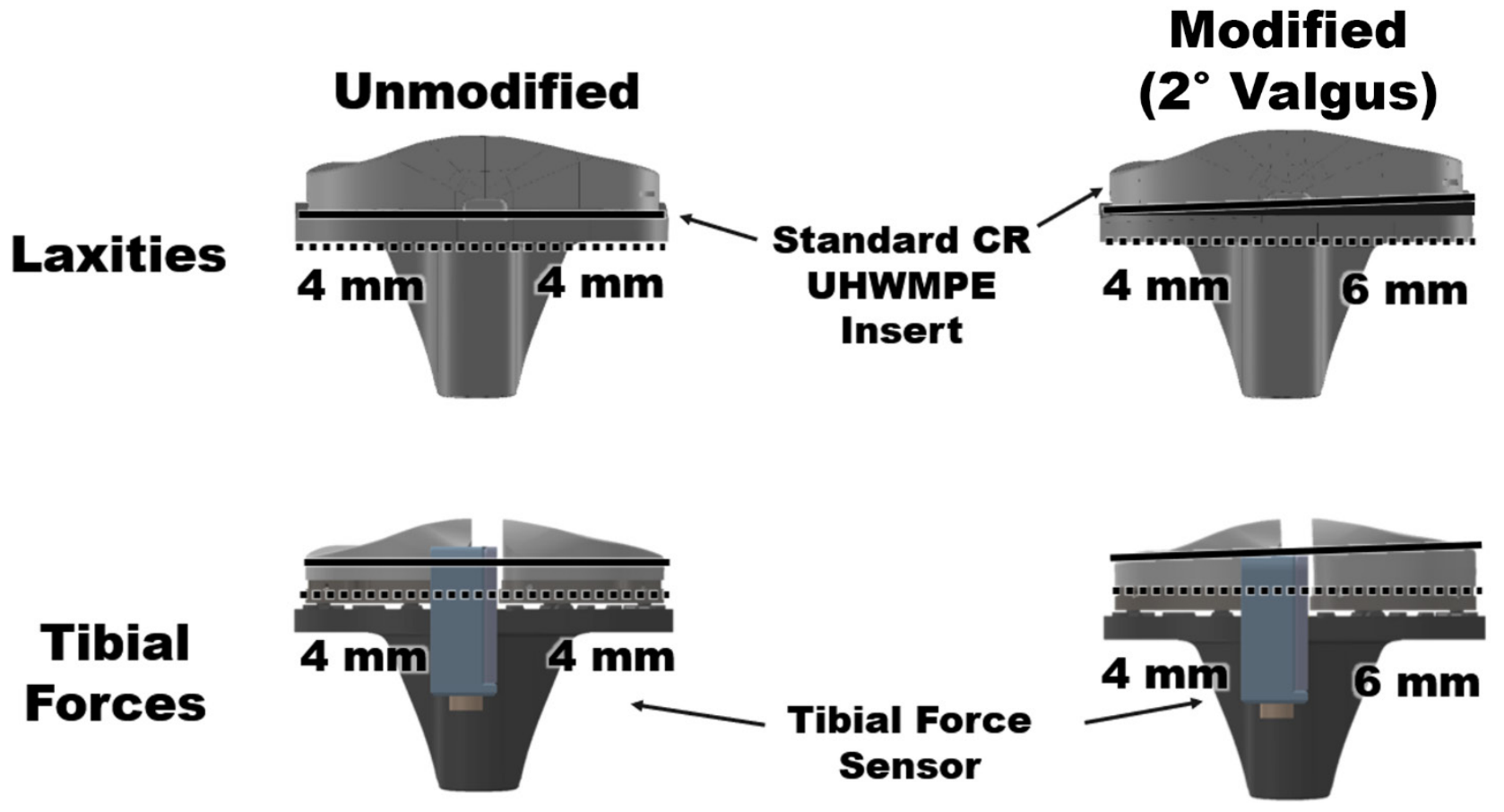

Figure 1. Renderings show the design of the modified tibial baseplates used when measuring the laxities (top row) and the design of the modified articular surface inserts used when measuring the tibial forces (bottom row). For the tibial baseplate, the modifications consisted of rotating the proximal features of the baseplate that secured the insert in place (solid black line) relative to the distal surface of the baseplate that interfaced with the cement mantle (dotted black line). Because the geometry of the distal surface was not changed, all baseplates could be implanted using the same cement mantle in each knee. The geometry of the proximal locking features of the tibial baseplate was also unchanged so the same standard UHMWPE (ultra-high molecular weight polyethylene) liner could be used in all knees. For the articular surface inserts, the modifications consisted of rotating the proximal articular surface (solid black line) relative to the distal surface that secured the inserts to the tibial force sensor (dotted black line) ${ }^{21}$. The modified tibial baseplate and articular surface inserts (left column) are an example of one of the four modified tibial baseplate and articular surface inserts created for each size tibial component. In the example case of a $2^{\circ}$ valgus malalignment, the medial side of the tibial component is approximately $2 \mathrm{~mm}$ thicker than the lateral side. 
medRxiv preprint doi: https://doi.org/10.1101/19013755; this version posted December 5, 2019. The copyright holder for this preprint (which was not certified by peer review) is the author/funder, who has granted medRxiv a license to display the preprint in perpetuity.

It is made available under a CC-BY-NC-ND 4.0 International license .

Tibial forces in the medial and lateral compartments were measured with each of the five sets

128 of 3D-printed articular surface inserts attached to the custom tibial force sensor ${ }^{21}$. The tibial force

129 sensor had the same exterior size and shape as the correctly sized Persona tibial baseplate and insert.

130 The tibial force sensor measured force independently in the medial and lateral compartments and over

131 the full surface area of the liner with a maximum root mean squared error of $6 \mathrm{~N}^{21 ; 39}$. Before testing,

132 each knee was passively flexed five times between $0^{\circ}$ and $120^{\circ}$ of flexion. The testing order of the five

133 sets of 3D-printed articular surface inserts was randomized. After inserting a randomly selected set of

134 3D-printed articular surface inserts, the patellar osteotomy was closed with two transverse screws. To

135 stabilize the TKA knee during flexion, constant forces of $26 \mathrm{~N}, 80 \mathrm{~N}$, and $15 \mathrm{~N}$ were applied to the

136 tendons of insertion of the semimembranosus/semitendinosus, quadriceps, and biceps femoris,

137 respectively. These forces were proportional to the muscle cross-sectional areas ${ }^{28}$ and smaller than

138 forces used to stabilize the TKA in other studies ${ }^{29-36}$. The tibial forces in the medial and lateral

139 compartments were measured at $30^{\circ}$ increments as the TKA was flexed passively from $0^{\circ}$ to $120^{\circ}$ and

140 back to $0^{\circ}$. After a test was completed for a set of 3D-printed articular surface inserts, the patellar

141 osteotomy was opened, a different set of 3D-printed articular surface inserts was inserted, the patellar

142 osteotomy was closed, and the test was repeated.

143

Next the varus and valgus laxities were measured with each of the five 3D-printed tibial

144 baseplates using a six degree-of-freedom load application system ${ }^{14,18,22}$. With the correctly sized

145 components implanted, each knee was subjected to a preconditioning protocol consisting of first

146 passively flexing and extending the knee five times from $0^{\circ}$ to $120^{\circ}$ flexion. Next, the knee was moved

147 to a flexion angle randomly selected from $0^{\circ}, 60^{\circ}$, and $120^{\circ}$ and then cycled five times between the

148 prescribed load limits for in four degrees of freedom in a random order ${ }^{37}$. The prescribed load limits

149 were $\pm 3 \mathrm{Nm}$ for I-E rotation ${ }^{38}, \pm 5 \mathrm{Nm}$ for $\mathrm{V}-\mathrm{V}$ rotation ${ }^{39}, \pm 45 \mathrm{~N}$ for A-P translation ${ }^{40}$, and $\pm 100 \mathrm{~N}$

150 for compression-distraction translation ${ }^{41}$. The limits of each load were selected to engage the soft

151 tissues sufficiently to load them beyond the initial toe region of the tibiofemoral joint's load- 
medRxiv preprint doi: https://doi.org/10.1101/19013755; this version posted December 5, 2019. The copyright holder for this preprint (which was not certified by peer review) is the author/funder, who has granted medRxiv a license to display the preprint in perpetuity.

It is made available under a CC-BY-NC-ND 4.0 International license .

152 deformation curve $\mathrm{e}^{39,40}$. The protocol was repeated for the remaining two flexion angles. After

153 completing preconditioning, the $\mathrm{V}-\mathrm{V}$ laxities were measured at $30^{\circ}$ increments from $0^{\circ}$ to $120^{\circ}$ in a

154 random order. The V-V laxities were computed as the difference between the V-V position of the tibia

155 under $\pm 5 \mathrm{Nm}$ and that in the unloaded knee ${ }^{22}$.

156 Repeatability of laxities and tibial forces was determined by measuring each variable over five

157 trials in three additional knee specimens. The greatest standard deviations of the V-V laxities and tibial

158 forces were $0.1^{\circ 22}$ and $12.9 \mathrm{~N}^{20}$, respectively.

159 Following University of California policies, this study did not require institutional review board

160 (IRB) approval because de-identified cadaveric specimens were used.

161 Statistical analysis

162 To determine the sensitivities of the tibial forces and V-V laxities to $\mathrm{V}-\mathrm{V}$ malalignment of the

163 tibial component, a simple linear regression with the intercept set to zero was performed for the

164 changes in the tibial forces and V-V laxities at each flexion angle. The changes were computed as the

165 difference between the tibial force/laxity with each modified component and that with the unmodified

166 reference component. The degree of either varus or valgus malalignment of the tibial component was

167 the independent variable, and the changes in each tibial force/laxity in all nine knees were the

168 dependent variables. The regressions were performed separately for varus malalignments and valgus

169 malalignments because each is likely to affect the medial and lateral structures differently due to the

170 differences in stiffness of the soft tissue restraints ${ }^{36,38,42}$. The slope of each regression line determined

171 the sensitivity of each tibial force variable/laxity to each direction of V-V malalignment of the tibial

172 component at that flexion angle.

To compare the sensitivities of tibial forces and $\mathrm{V}-\mathrm{V}$ laxities to $\mathrm{V}-\mathrm{V}$ malalignments of the

174 tibial component, the signal-to-noise ratios (i.e., absolute values of the ratios of the sensitivities to

175 previously reported measurement errors of either optical motion capture systems or intraoperative

176 tibial force sensors) were computed. Measurement errors (i.e., noise levels) of $0.7^{\circ}$ were used for the 
177 laxities $^{15}$. Measurement errors (i.e., noise level) of $14 \mathrm{~N}^{16}$ were used for the tibial forces. The signal-to-

178 noise ratios were computed for each sensitivity at each flexion angle.

180 malalignment of the tibial component, the $95 \%$ tolerance limits, which bound the predicted range of

$18195 \%$ of the sensitivities in the population with a $95 \%$ confidence level $^{43}$, were computed for the

182 sensitivity of each variable at each flexion angle (Equation 1). With nine knee specimens included in

183 the present study, the tolerance factor $(k)$ was computed to be $3.55^{43}$. Also, a simple linear regression

184 was performed for each knee independently with the degree of either varus or valgus malalignment of

185 the tibial component as the independent variable and the changes in each tibial force/laxity in each

186 knee as the dependent variable.

187 Tolerance Limits $=$ sensitivity $\pm k \times$ standard error of sensitivity $\times \sqrt{\text { number of knees }}$

(Equation 1) 
medRxiv preprint doi: https://doi.org/10.1101/19013755; this version posted December 5, 2019. The copyright holder for this preprint (which was not certified by peer review) is the author/funder, who has granted medRxiv a license to display the preprint in perpetuity.

It is made available under a CC-BY-NC-ND 4.0 International license .

\section{Results}

191 flexion (Table 1, Figure 2). Valgus malalignments caused changes in the tibial forces throughout

192 flexion, but varus malalignments caused changes only at $0^{\circ}$ flexion. Valgus malalignments primarily

193 increased the medial tibial force. Varus malalignments primarily increased the lateral tibial force at $0^{\circ}$

194 flexion.

Table 1. Mean sensitivity (i.e. slope), coefficient of determination $\left(r^{2}\right), p$-value, and 95\% tolerance limits of the sensitivity for linear regressions between the change in the medial and lateral tibial forces and either the degree of varus or valgus malalignment of the tibial component (TC) (independent variables).

\begin{tabular}{|c|c|c|c|c|c|c|}
\hline & & & & & \\
\hline & & $0^{\circ}$ flexion & $30^{\circ}$ flexion & $60^{\circ}$ flexion & $90^{\circ}$ flexion & $120^{\circ}$ flexion \\
\hline \multirow{4}{*}{$\begin{array}{c}\text { Sensitivity of } \\
\text { Lateral Tibial } \\
\text { Force to Varus } \\
\text { Malalignment }\end{array}$} & Slope & $78.6 \mathrm{~N} / \mathrm{deg}$ & $7.2 \mathrm{~N} / \mathrm{deg}$ & $4.9 \mathrm{~N} / \mathrm{deg}$ & $5.5 \mathrm{~N} / \mathrm{deg}$ & $4.4 \mathrm{~N} / \mathrm{deg}$ \\
\hline & $r^{2}$ & 0.68 & 0.39 & 0.52 & 0.48 & 0.43 \\
\hline & p-value & $<0.0005$ & $<0.0005$ & $<0.0005$ & $<0.0005$ & $<0.0005$ \\
\hline & $\begin{array}{l}95 \% \text { tolerance } \\
\text { limits }\end{array}$ & $\begin{array}{c}7.7 \text { to } 149.6 \\
\text { N/deg }\end{array}$ & $\begin{array}{l}-4.7 \text { to } 19.1 \\
\text { N/deg }\end{array}$ & $\begin{array}{c}-1.4 \text { to } 11.2 \\
\mathrm{~N} / \mathrm{deg}\end{array}$ & $\begin{array}{c}-2.1 \text { to } 13.1 \\
\mathrm{~N} / \mathrm{deg}\end{array}$ & $\begin{array}{l}-2.2 \text { to } 11.0 \\
\mathrm{~N} / \mathrm{deg}\end{array}$ \\
\hline \multirow{4}{*}{$\begin{array}{l}\text { Sensitivity of } \\
\text { Medial Tibial } \\
\text { Force to } \\
\text { Valgus } \\
\text { Malalignment }\end{array}$} & Slope & $118.3 \mathrm{~N} / \mathrm{deg}$ & $35.9 \mathrm{~N} / \mathrm{deg}$ & $39.5 \mathrm{~N} / \mathrm{deg}$ & $30.4 \mathrm{~N} / \mathrm{deg}$ & $18.2 \mathrm{~N} / \mathrm{deg}$ \\
\hline & $r^{2}$ & 0.63 & 0.49 & 0.53 & 0.44 & 0.24 \\
\hline & p-value & $<0.0005$ & $<0.0005$ & $<0.0005$ & $<0.0005$ & $<0.0005$ \\
\hline & $\begin{array}{l}95 \% \text { tolerance } \\
\text { limits }\end{array}$ & $\begin{array}{c}-1.4 \text { to } 238.0 \\
\mathrm{~N} / \mathrm{deg}\end{array}$ & $\begin{array}{c}-12.9 \text { to } 84.7 \\
\mathrm{~N} / \mathrm{deg}\end{array}$ & $\begin{array}{c}-10.1 \text { to } 89.1 \\
\text { N/deg }\end{array}$ & $\begin{array}{c}-15.0 \text { to } 75.7 \\
\mathrm{~N} / \mathrm{deg}\end{array}$ & $\begin{array}{c}-25.0 \text { to } 61.5 \\
\text { N/deg }\end{array}$ \\
\hline
\end{tabular}




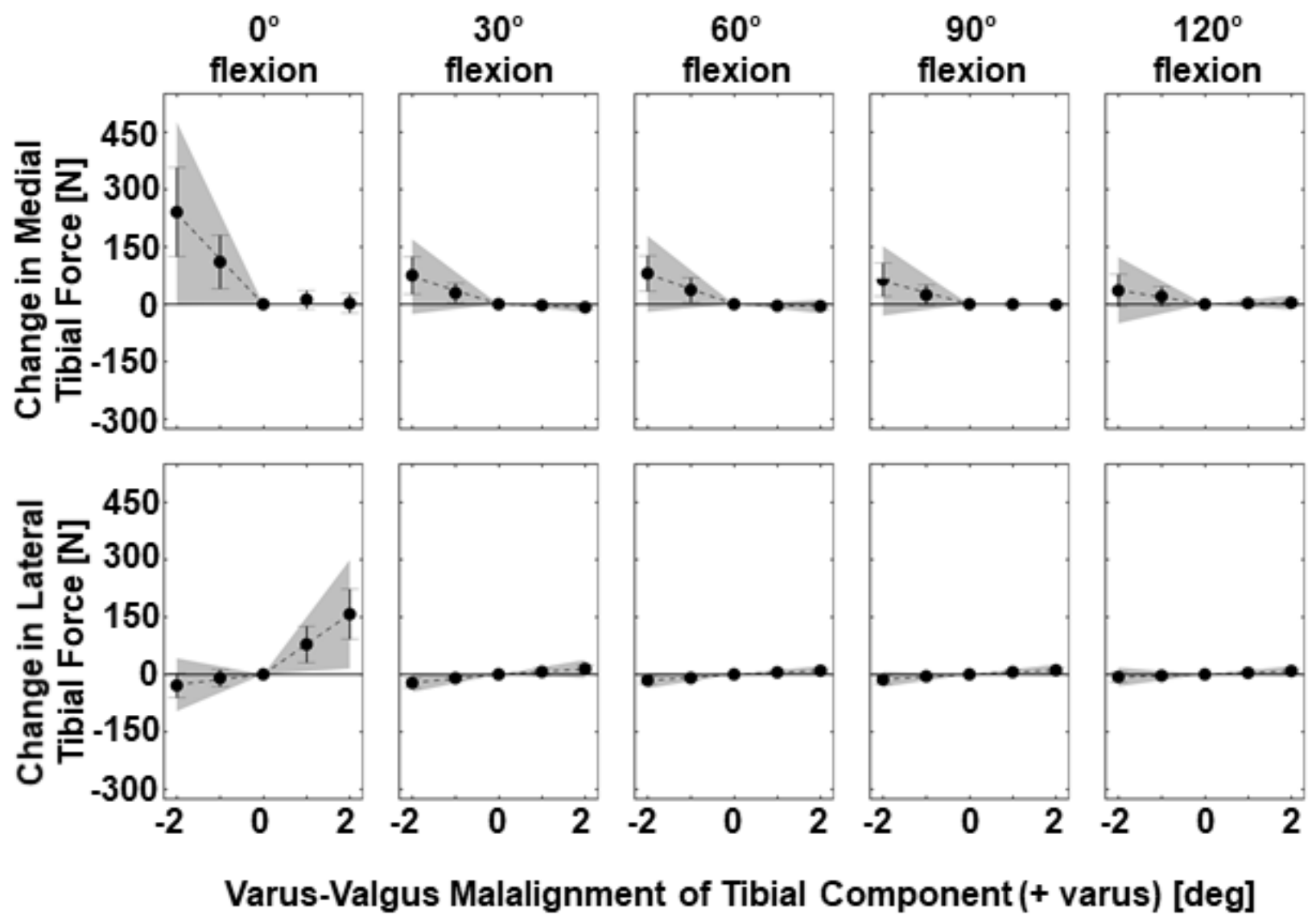

Figure 2. Plots show means (points) and standard deviations (error bars) of the changes in the medial and lateral tibial forces caused by $V$-V malalignment of the tibial component. Dotted lines show the significant relationships $(p<0.05)$ between the changes in tibial force variables and $V-V$ malalignments (Table 1). The shaded grey regions show the $95 \%$ tolerance intervals for the sensitivities.

Unlike the sensitivities of tibial forces, which were greatest at $0^{\circ}$ flexion, the sensitivities of $\mathrm{V}$ -

198 V laxities to V-V malalignment were greatest in mid to deep flexion (Table 2). Valgus malalignments

199 decreased both varus and valgus laxities with the greatest sensitivity occurring at $120^{\circ}$ flexion for

200 valgus laxity. Varus malalignments primarily decreased the varus laxities with the greatest sensitivity

201 occurring at $60^{\circ}$ flexion. 
medRxiv preprint doi: https://doi.org/10.1101/19013755; this version posted December 5, 2019. The copyright holder for this preprint (which was not certified by peer review) is the author/funder, who has granted medRxiv a license to display the preprint in perpetuity.

It is made available under a CC-BY-NC-ND 4.0 International license .

Table 2. Mean sensitivity (i.e. slope), coefficient of determination $\left(r^{2}\right), p$-value, and 95\% tolerance limits of the sensitivity for linear regressions between the changes in the laxities (dependent variables) and the degree of either varus or valgus malalignment of the tibial component (TC) (independent variables).

\begin{tabular}{|c|c|c|c|c|c|c|}
\hline & $0^{\circ}$ flexion & $30^{\circ}$ flexion & $60^{\circ}$ flexion & $90^{\circ}$ flexion & $120^{\circ}$ flexion \\
\hline \multirow{4}{*}{$\begin{array}{l}\text { Sensitivity of } \\
\text { Varus Laxity } \\
\text { to Varus } \\
\text { Malalignment }\end{array}$} & Slope & $-0.2 \mathrm{deg} / \mathrm{deg}$ & $-0.6 \mathrm{deg} / \mathrm{deg}$ & $-0.6 \mathrm{deg} / \mathrm{deg}$ & $-0.6 \mathrm{deg} / \mathrm{deg}$ & $-0.6 \mathrm{deg} / \mathrm{deg}$ \\
\hline & $\mathrm{r}^{2}$ & 0.39 & 0.88 & 0.80 & 0.68 & 0.63 \\
\hline & $\mathrm{p}$-value & $<0.0005$ & $<0.0005$ & $<0.0005$ & $<0.0005$ & $<0.0005$ \\
\hline & $\begin{array}{l}95 \% \text { tolerance } \\
\text { limits } \\
\end{array}$ & $\begin{array}{c}-0.7 \text { to } 0.2 \\
\mathrm{deg} / \mathrm{deg}\end{array}$ & $\begin{array}{c}-0.9 \text { to }-0.3 \\
\mathrm{deg} / \mathrm{deg}\end{array}$ & $\begin{array}{c}-1.0 \text { to }-0.2 \\
\mathrm{deg} / \mathrm{deg}\end{array}$ & $\begin{array}{c}-1.2 \text { to }-0.1 \\
\mathrm{deg} / \mathrm{deg}\end{array}$ & $\begin{array}{c}-1.2 \text { to } 0.0 \\
\mathrm{deg} / \mathrm{deg}\end{array}$ \\
\hline \multirow{4}{*}{$\begin{array}{l}\text { Sensitivity of } \\
\text { Valgus Laxity } \\
\text { to Valgus } \\
\text { Malalignment }\end{array}$} & Slope & $-0.1 \mathrm{deg} / \mathrm{deg}$ & $-0.3 \mathrm{deg} / \mathrm{deg}$ & $-0.1 \mathrm{deg} / \mathrm{deg}$ & $-0.2 \mathrm{deg} / \mathrm{deg}$ & $-0.4 \mathrm{deg} / \mathrm{deg}$ \\
\hline & $\mathrm{r}^{2}$ & 0.20 & 0.30 & 0.05 & 0.24 & 0.44 \\
\hline & $\mathrm{p}$-value & $<0.0005$ & $<0.0005$ & 0.09 & $<0.0005$ & $<0.0005$ \\
\hline & $\begin{array}{l}95 \% \text { tolerance } \\
\text { limits }\end{array}$ & $\begin{array}{c}-0.5 \text { to } 0.2 \\
\text { deg/deg }\end{array}$ & $\begin{array}{c}-0.8 \text { to } 0.3 \\
\mathrm{deg} / \mathrm{deg}\end{array}$ & $\begin{array}{c}-0.9 \text { to } 0.6 \\
\text { deg/deg }\end{array}$ & $\begin{array}{c}-0.7 \text { to } 0.3 \\
\text { deg/deg }\end{array}$ & $\begin{array}{c}-1.1 \text { to } 0.2 \\
\text { deg/deg }\end{array}$ \\
\hline
\end{tabular}

The signal-to-noise ratios of the tibial forces were often greater than those of the $\mathrm{V}$-V laxities

205 (Figure 3). For the tibial forces, the greatest ratios occurred at $0^{\circ}$ flexion. These were $5.6 \mathrm{deg}^{-1}$ of varus 206 malalignment for the lateral tibial force and $8.5 \mathrm{deg}^{-1}$ of valgus malalignment for the medial tibial 207 force. In comparison, for the V-V laxities, the greatest ratios were $0.9 \mathrm{deg}^{-1}$ of varus malalignment for 208 the varus laxity at $90^{\circ}$ of flexion and $0.6 \mathrm{deg}^{-1}$ of valgus malalignment for the valgus laxity at $120^{\circ}$ of 209 flexion (Figure 3). 

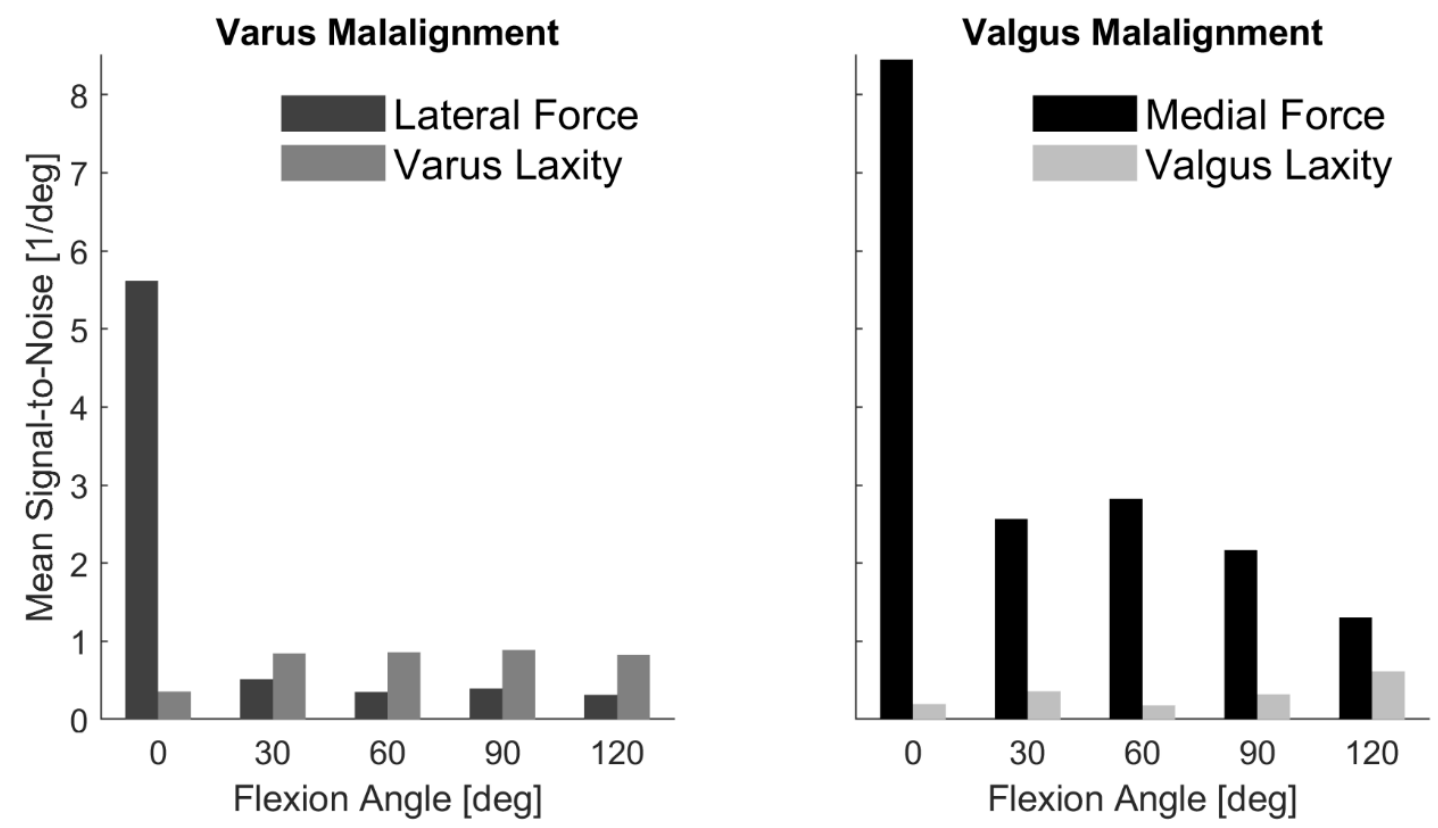

Figure 3. Bar plots show the mean signal-to-noise ratios (i.e., ratios of the sensitivities to previously reported measurement errors of either optical motion capture systems or intraoperative tibial force sensors) for the medial and lateral forces, and the varus and valgus laxities from $0^{\circ}$ to $120^{\circ}$.

The sensitivities of both tibial forces and laxities to V-V malalignment varied widely from knee

212 to knee (Tables 1 and 2). For the tibial forces, the $95 \%$ tolerance limits of the sensitivities were widest

213 at $0^{\circ}$ flexion (medial tibial force $=-1$ to $238 \mathrm{~N} / \mathrm{deg}$ of valgus malalignment; lateral tibial force $=8$ to

$214150 \mathrm{~N} / \mathrm{deg}$ of varus malalignment) (Table 1, Figure 2). For the varus laxities, the 95\% tolerance limits

215 for the sensitivities were widest at $90^{\circ}$ flexion (-1.2 to $-0.1 \mathrm{deg} / \mathrm{deg}$ of varus malalignment) (Table 2).

216 For the valgus laxities, the $95 \%$ tolerance limits for the sensitivities were widest at $120^{\circ}$ flexion $(-1.1$

217 to $0.2 \mathrm{deg} / \mathrm{deg}$ of valgus malalignment) (Table 2).

Although the sensitivities varied widely from knee to knee, the strength of the linear

219 relationships did not. The coefficients of determination $\left(\mathrm{r}^{2}\right)$ for the sensitivities of tibial forces across

220 the nine knees were most consistent at $0^{\circ}$ flexion (range medial tibial force to valgus malalignment $=$

2210.80 to 1.00 and range lateral tibial force to varus malalignment $=0.83$ to 1.00$)($ Table 3$)$. The $r^{2}-$

222 values for the sensitivities were most consistent across the nine knees for the V-V laxities at $60^{\circ}$ 
medRxiv preprint doi: https://doi.org/10.1101/19013755; this version posted December 5, 2019. The copyright holder for this preprint (which was not certified by peer review) is the author/funder, who has granted medRxiv a license to display the preprint in perpetuity.

It is made available under a CC-BY-NC-ND 4.0 International license .

223 flexion (range varus laxity to varus malalignment $=0.97$ to 1.00 , range valgus laxity to valgus

224 malalignment $=0.58$ to 1.00$)$.

Table 3. Mean sensitivities and coefficients of determination $\left(r^{2}\right)$ for linear regressions between the change in the medial and lateral tibial forces (dependent variables) and either the degree of varus or valgus malalignment of the tibial component (TC) (independent variables) for each of the nine knees at $0^{\circ}$ flexion.

\begin{tabular}{|c|c|c|c|c|}
\hline \multirow{4}{*}{ Specimen } & \multicolumn{4}{|c|}{ Mean slope, $\left(\mathrm{r}^{2}\right)$} \\
\cline { 2 - 5 } & \multicolumn{2}{|c|}{$\begin{array}{c}\text { Medial Tibial Force } \\
{[\mathrm{N} / \mathrm{deg}]}\end{array}$} & \multicolumn{2}{c|}{$\begin{array}{c}\text { Lateral Tibial Force } \\
{[\mathrm{N} / \mathrm{deg}]}\end{array}$} \\
\cline { 2 - 5 } & $\begin{array}{c}\text { TC } \\
\text { Varus }\end{array}$ & $\begin{array}{c}\text { TC } \\
\text { Valgus }\end{array}$ & $\begin{array}{c}\text { TC } \\
\text { Varus }\end{array}$ & $\begin{array}{c}\text { TC } \\
\text { Valgus }\end{array}$ \\
\hline \multirow{2}{*}{1} & 21.5 & -212.9 & 63.9 & $\begin{array}{c}3.8 \\
(1.00)\end{array}$ \\
& $(0.65)$ & $(1.00)$ & $(0.23)$ \\
\hline \multirow{2}{*}{2} & -13.4 & -87.9 & 116.0 & 26.6 \\
& $(0.91)$ & $(0.80)$ & $(0.97)$ & $(0.86)$ \\
\hline \multirow{2}{*}{3} & 5.5 & -86.3 & 52.6 & 15.2 \\
& $(0.97)$ & $(1.00)$ & $(0.97)$ & $(0.93)$ \\
\hline \multirow{2}{*}{4} & 4.6 & -179.6 & 145.4 & 17.8 \\
& $(0.08)$ & $(0.99)$ & $(0.95)$ & $(0.73)$ \\
\hline \multirow{2}{*}{5} & 13.9 & -142.1 & 60.5 & 17.1 \\
& $(0.96)$ & $(1.00)$ & $(0.97)$ & $(0.16)$ \\
\hline \multirow{2}{*}{6} & 20.1 & -147.8 & 30.8 & 24.3 \\
& $(0.79)$ & $(1.00)$ & $(0.83)$ & $(1.00)$ \\
\hline \multirow{2}{*}{7} & -12.9 & -35.3 & 67.1 & 0.3 \\
& $(0.84)$ & $(0.99)$ & $(1.00)$ & $(0.06)$ \\
\hline \multirow{2}{*}{8} & -13.1 & -128.4 & 86.0 & 24.8 \\
& $(1.00)$ & $(1.00)$ & $(1.00)$ & $(1.00)$ \\
\hline \multirow{2}{*}{9} & 3.2 & -44.5 & 85.2 & -8.9 \\
& $(0.93)$ & $(0.94)$ & $(0.99)$ & $(0.19)$ \\
\hline
\end{tabular}

226 Discussion

There were three key findings in the present study. The first key finding was that in general the

tibial forces were most sensitive to overstuffing near extension, and the laxities were most sensitive in

mid to deep flexion. The second key finding was that tibial forces are better than laxities for

230 identifying and correcting V-V malalignments of the tibial component that overstuff a compartment

231 because the signal-to-noise ratios are greater by about an order of magnitude. The third key finding

232 was that there was wide variability in the sensitivities of both the tibial forces and the laxities to $\mathrm{V}-\mathrm{V}$ 
medRxiv preprint doi: https://doi.org/10.1101/19013755; this version posted December 5, 2019. The copyright holder for this preprint (which was not certified by peer review) is the author/funder, who has granted medRxiv a license to display the preprint in perpetuity.

It is made available under a CC-BY-NC-ND 4.0 International license .

233

malalignments between knees; however, each knee demonstrated strong linear relationships between changes in tibial force/laxities and $\mathrm{V}-\mathrm{V}$ malalignments.

The first key finding that tibial forces were most sensitive to overstuffing near extension and the laxities were most sensitive in mid to deep flexion is consistent with the expected changes in the tension of the soft tissue restraints. Overstuffing increases the length of the soft tissue restraints in the overstuffed compartment, which in turn can increase the soft tissue tension or decrease the laxity depending on the initial V-V laxity. If the initial V-V laxity is minimal, thus indicating some degree of pretension in the soft tissue restraints, then overstuffing will further increase the tension and thus the tibial force, which was observed at $0^{\circ}$ flexion where $\mathrm{V}-\mathrm{V}$ laxity is minimal ${ }^{22}$; the $\mathrm{V}-\mathrm{V}$ laxities will be relatively unaffected because the soft tissue restraints are stiff. However, as the V-V laxity increases with flexion ${ }^{22}$ indicating that the soft tissue restraints become more lax, the effect of overstuffing on tibial forces is mitigated, but the effect on V-V laxities is amplified because overstuffing makes the knee less lax in the particular compartment overstuffed.

Regarding the second key finding, the signal-to-noise ratio indicates how well actual changes in force/laxity can be detected in the presence of measurement errors. Because all the signal-to-noise ratios for the changes in the V-V laxities were less than 1 (Figure 3), surgeons would have a difficult time detecting actual changes from measurement errors. However, many of the signal-to-noise ratios for changes in tibial forces, especially those at $0^{\circ}$ flexion where the tibial forces $\mathrm{w}$ greates $\mathrm{t}^{20}$, are much greater than 1 . The relatively large signal-to-noise ratios indicate that actual changes in tibial forces due to $\mathrm{V}-\mathrm{V}$ malalignments of the tibial component should dominate over measurement errors (Figure 3). Therefore, tibial forces are better than V-V laxities for identifying and correcting V-V malalignments of the tibial component that overstuff a compartment because guiding re-cuts based on the sensitivities in tibial forces should lead to more accurate re-cuts.

The second key finding that the tibial forces are more useful than laxities for identifying and correcting V-V malalignments of the tibial component that overstuff a compartment is supported by 
medRxiv preprint doi: https://doi.org/10.1101/19013755; this version posted December 5, 2019. The copyright holder for this preprint (which was not certified by peer review) is the author/funder, who has granted medRxiv a license to display the preprint in perpetuity.

It is made available under a CC-BY-NC-ND 4.0 International license .

prior clinical and biomechanical studies. A previous clinical study showed that it is challenging for surgeons to detect high tibial forces using a standard gap-balancing approach for mechanically aligned $\mathrm{TKA}^{7}$, which is based on the joint laxity. Without the use of an intraoperative tibial force sensor, TKAs deemed to be correctly balanced exhibited mean compartment loads as high as $352 \mathrm{~N}$, which are much greater than those in the native knee that have been reported as $114 \mathrm{~N}$ on average ${ }^{13}$. Biomechanically, because the soft tissues restraints are often already loaded into their linear high stiffness regions near full extension ${ }^{39,40}$, additional deformation due to overstuffing does not change their stiffness. Thus, the laxity, which is a cumulative measure of the deformations of many soft tissue restraints, would also not change (Table 2). Therefore, intraoperative laxity assessments are likely better for detecting an understuffed compartment where gaps between the components can be detected visually.

Regarding the third key finding, the large but variable sensitivities of tibial forces to overstuffing caused by V-V malalignments of the tibial component have important clinical implications for balancing a kinematically aligned TKA. The wide tolerance intervals on the sensitivities are supported by both the wide variability in the mechanical properties of the primary soft tissue restraints ${ }^{44-46}$ and the wide variability in the tibial forces in the native knee ${ }^{13}$. As described previously, balancing of the medial and lateral soft tissues in calipered kinematically aligned TKA is performed by adjusting the $\mathrm{V}-\mathrm{V}$ orientation of the tibial resection after confirming that the femoral component is kinematically aligned ${ }^{19,25}$. Thus, the sensitivities determined in the present study provide quantitative guidance for how large of an adjustment is necessary to achieve a desired reduction in the tibial forces when an intraoperative tibial force sensor is used. However, the wide variability of these sensitivities raises concern with using the mean values for all knees. An illustrative example about how this variability might increase the time and complexity of the balancing procedure is presented in Supplement 1 .

Because there was a strong linear relationship between changes in tibial forces and $\mathrm{V}-\mathrm{V}$ 
medRxiv preprint doi: https://doi.org/10.1101/19013755; this version posted December 5, 2019. The copyright holder for this preprint (which was not certified by peer review) is the author/funder, who has granted medRxiv a license to display the preprint in perpetuity.

It is made available under a CC-BY-NC-ND 4.0 International license.

283 sensitivity (Figure 4) to overcome the wide patient-to-patient variability. In this procedure, the surgeon

284 would first record the initial tibial force values. For example, assume that the initial medial and lateral

285 tibial forces are 300 and $65 \mathrm{~N}$, respectively, and the surgeon desires to match the mean tibial forces of

286 the native knee $\left(114 \mathrm{~N}\right.$ in the medial compartment and $63 \mathrm{~N}$ in the lateral compartment $\left.{ }^{13}\right)$ by

287 performing a varus re-cut. Next, the surgeon would insert a trial that simulates a $1^{\circ}$ varus re-cut and

288 again record the medial and lateral tibial forces. The difference between the medial tibial force before

289 and after inserting the $1^{\circ}$ varus re-cut trial is the sensitivity of the medial tibial force to valgus tibial

290 malalignment. By determining this patient-specific sensitivity, the re-cut also would be patient-specific

291 (Figure 4). This approach would be useful in patients with OA because it is based on the current state

292 of the joint; thus, utilizing this simple patient-specific approach would overcome one methodological

293 issue with this study described below which is that the knees did not have OA. 
High-sensitivity Knee (Specimen 1)
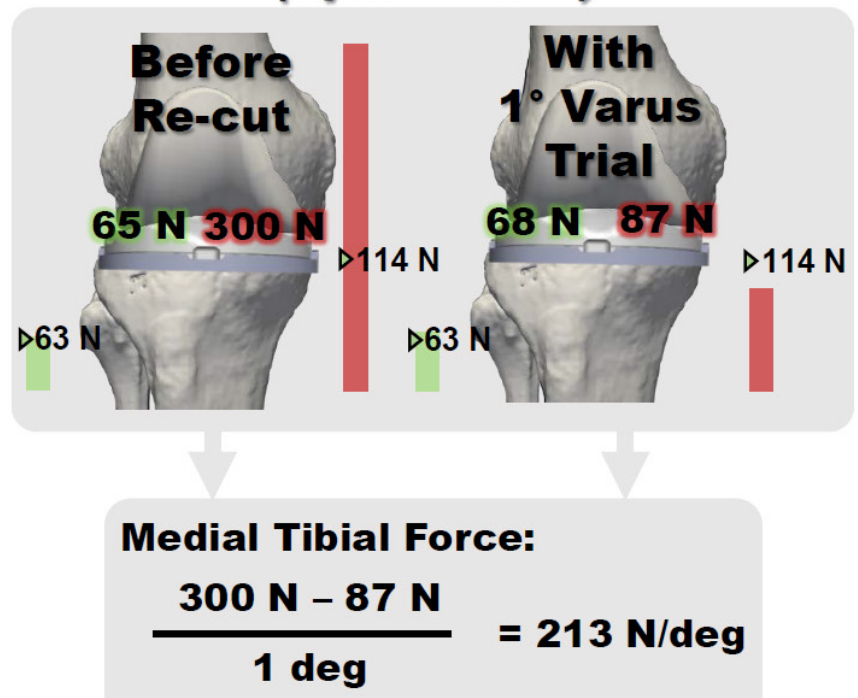

Lateral Tibial Force:

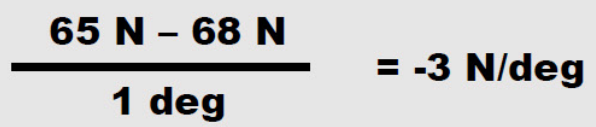

Low-sensitivity Knee (Specimen 7)

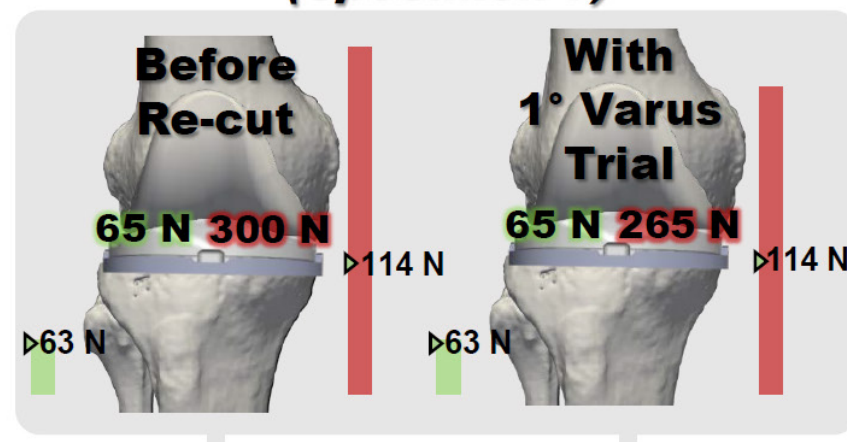

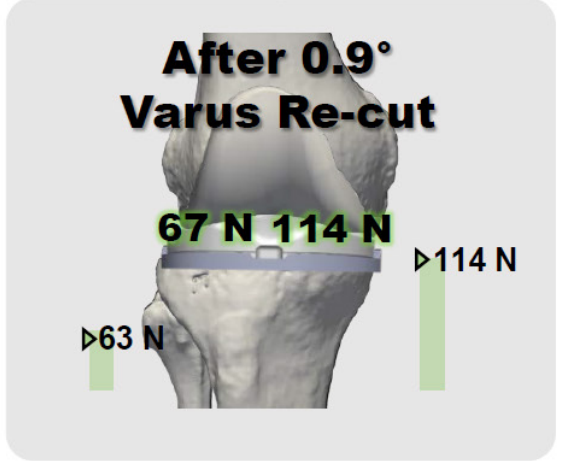

Figure 4. Schematic shows representative examples of how patient-specific sensitivities can be determined using a small trial re-cut (e.g., $1^{\circ}$ varus) and then how the correct re-cut for that patient can be determined based on the patient-specific sensitivity. Because the target tibial forces for a specific patient are unknown, the mean tibial forces at $0^{\circ}$ flexion in the native knee (medial force $=$ $114 \mathrm{~N}$ and lateral force $=63 \mathrm{~N})^{13}$ are used as the target for this example.

Three methodological issues should be acknowledged because of their potential to affect the

results. One methodologic issue concerns the alignment of the tibial component in the reference 
medRxiv preprint doi: https://doi.org/10.1101/19013755; this version posted December 5, 2019. The copyright holder for this preprint (which was not certified by peer review) is the author/funder, who has granted medRxiv a license to display the preprint in perpetuity.

It is made available under a CC-BY-NC-ND 4.0 International license .

tibial forces after KA TKA are comparable to those of the native knee ${ }^{20}$ and (2) the laxities and neutral

300 positions were largely not different from those of the native knee ${ }^{22}$. Thus, if present, then $\mathrm{V}-\mathrm{V}$

301 malalignments of the reference tibial components were likely small as described previously in the

302 Methods section ${ }^{2}$. A second methodologic issue was that this study was performed in knees without

303 OA. Thus, the sensitivities might differ in knees with end-stage OA. Additional changes to the

304 mechanical properties of the medial and lateral soft tissue restraints that likely occur in some OA

305 patients would likely increase the variability in the sensitivities. However, while the exact sensitivities

306 might change in OA knees, the conclusions drawn in the present study that tibial forces are better than

307 laxities for detecting overstuffing should still apply to OA patients. Further, using the simple patient-

308 specific approach described previously would enable the patient-specific sensitivity to be determined

309 regardless of the condition of the soft tissue restraints. The third methodological issue is that only nine

310 knee specimens were included. While this number was sufficient to detect strong relationships between

$311 \mathrm{~V}-\mathrm{V}$ malalignment and changes in tibial forces and laxities, this group likely does not capture all the

312 knee-to-knee variability in the population. To best account for this issue, we computed tolerance

313 intervals to represent the predicted range because tolerance intervals take into account the sample size

314 when predicting the range of the population.

315 In conclusion, measuring changes in tibial forces is more useful than measuring changes in

316 laxities for identifying and correcting $\mathrm{V}-\mathrm{V}$ malalignments of the tibial component that overstuff a

317 compartment. Because of the wide variability in sensitivities between knees, a patient-specific

318 procedure is needed to adjust the tibial resection when high tibial forces are registered due to

319 overstuffing of a compartment. Using the simple patient-specific procedure proposed in this study,

320 surgeons can determine patient-specific sensitivities of tibial forces to $\mathrm{V}-\mathrm{V}$ malalignments of the tibial

321 component and use these patient-specific sensitivities to determine the re-cut necessary to correct

322 overstuffing caused by V-V malalignment of the tibial component. These patient-specific re-cuts

323 should reduce the risk of improperly tensioned soft tissue restraints and unnecessary ligament releases. 
medRxiv preprint doi: https://doi.org/10.1101/19013755; this version posted December 5, 2019. The copyright holder for this preprint (which was not certified by peer review) is the author/funder, who has granted medRxiv a license to display the preprint in perpetuity.

It is made available under a CC-BY-NC-ND 4.0 International license.

\section{Acknowledgements}

325 The authors acknowledge the support of the National Science Foundation (Award No. CBET-

326 067527) and Zimmer Biomet (Award No. CW88095). Additionally, the authors wish to thank

327 individuals who donate their bodies and tissues for the advancement of education and research.

328

329 One author, MLH, received research funding from Zimmer Biomet for this study and receives research

330 support from Medacta that is not related to this study. One author, SMH, receives IP royalties from and

331 is a paid consultant and presenter/speaker for Biomet Sports Medicine and Medacta, and receives

332 research support from Medacta, which are all unrelated to this study. 
medRxiv preprint doi: https://doi.org/10.1101/19013755; this version posted December 5, 2019. The copyright holder for this preprint (which was not certified by peer review) is the author/funder, who has granted medRxiv a license to display the preprint in perpetuity.

It is made available under a CC-BY-NC-ND 4.0 International license .

\section{References}

1. Johnson, JM, Mahfouz, MR, Midillioglu, MR, et al. 2017. Three-dimensional analysis of the tibial resection plane relative to the arthritic tibial plateau in total knee arthroplasty. J Exp Orthop 4:1 27.

2. Nedopil, AJ, Singh, AK, Howell, SM, Hull, ML. 2018. Does Calipered Kinematically Aligned TKA Restore Native Left to Right Symmetry of the Lower Limb and Improve Function? J Arthroplasty 33:2 398-406.

3. Nedopil, AJ, Howell, SM, Hull, ML. 2016. Does Malrotation of the Tibial and Femoral Components Compromise Function in Kinematically Aligned Total Knee Arthroplasty? Orthop Clin North Am 47:1 41-50.

4. Hashemi, J, Chandrashekar, N, Gill, B, et al. 2008. The geometry of the tibial plateau and its influence on the biomechanics of the tibiofemoral joint. J Bone Joint Surg Am 90:12 2724-2734.

5. Harmon, MK, Markovich, GD, Banks, SA, Hodge, WA. 1998. Wear Patterns on Tibial Plateaus From Varus and Valgus Osteoarthritic Knees. Clin Orthop Relat Res 352:7 149-158.

6. Nedopil, AJ, Howell, SM, Hull, ML. 2017. What mechanisms are associated with tibial component failure after kinematically-aligned total knee arthroplasty? Int Orthop 41:8 1561-1569.

7. Elmallah, RK, Mistry, JB, Cherian, JJ, et al. 2016. Can We Really "Feel" a Balanced Total Knee Arthroplasty? J Arthroplasty 31:9 Suppl 102-105.

8. Siston, RA, Maack, TL, Hutter, EE, et al. 2012. Design and cadaveric validation of a novel device to quantify knee stability during total knee arthroplasty. J Biomech Eng 134:11 115001.

9. Camarata, DA. 2014. Soft tissue balance in total knee arthroplasty with a force sensor. Orthop Clin North Am 45:2 175-184.

10. Gustke, KA, Golladay, GJ, Roche, MW, et al. 2014. A new method for defining balance: promising short-term clinical outcomes of sensor-guided TKA. J Arthroplasty 29:5 955-960.

11. Walker, PS, Meere, PA, Bell, CP. 2014. Effects of surgical variables in balancing of total knee replacements using an instrumented tibial trial. Knee 21:1 156-161.

12. Riviere, C, Iranpour, F, Auvinet, E, et al. 2017. Alignment options for total knee arthroplasty: A systematic review. Orthop Traumatol Surg Res 103:7 1047-1056.

13. Verstraete, MA, Meere, PA, Salvadore, G, et al. 2017. Contact forces in the tibiofemoral joint from soft tissue tensions: Implications to soft tissue balancing in total knee arthroplasty. J Biomech 58195202.

14. Roth, JD, Hull, ML, Howell, SM. 2015. The Limits of Passive Motion Are Variable Between and Unrelated Within Normal Tibiofemoral Joints. J Orthop Res 33:11 1594-1602.

15. Maletsky, LP, Sun, J, Morton, NA. 2007. Accuracy of an optical active-marker system to track the relative motion of rigid bodies. J Biomech 40:3 682-685.

16. Nicolet-Petersen, SJ, Howell, SM, Hull, M. 2018. Force and Contact Location Measurement Errors of the VERASENSE. J Biomech Eng 140:12 124502-124502-124506.

17. Faul, F, Erdfelder, E, Buchner, A, Lang, AG. 2009. Statistical power analyses using G*Power 3.1: tests for correlation and regression analyses. Behav Res Methods 41:4 1149-1160.

18. Bach, JM, Hull, ML. 1995. A new load application system for in vitro study of ligamentous injuries to the human knee joint. J Biomech Eng 117:4 373-382. 
19. Roth, JD, Howell, SM, Hull, ML. 2015. Native Knee Laxities at $0^{\circ}, 45^{\circ}$, and $90^{\circ}$ of Flexion and Their Relationship to the Goal of the Gap-Balancing Alignment Method of Total Knee Arthroplasty. J Bone Joint Surg Am 97:20 1678-1684.

20. Roth, JD, Howell, SM, Hull, ML. 2018. Kinematically aligned total knee arthroplasty limits high tibial forces, differences in tibial forces between compartments, and abnormal tibial contact kinematics during passive flexion. Knee Surg Sports Traumatol Arthrosc 26:6 1589-1601. Forces and Contact Locations In Vitro After Total Knee Arthroplasty. J Biomech Eng 139:4 041001041001-041008. from native after kinematically aligned TKA using cruciate retaining implants. J Orthop Res 37:2 358369.

23. Arnold, EM, Ward, SR, Lieber, RL, Delp, SL. 2010. A model of the lower limb for analysis of human movement. Ann Biomed Eng 38:2 269-279.

24. Markolf, KL, Gorek, JF, Kabo, JM, Shapiro, MS. 1990. Direct measurement of resultant forces in the anterior cruciate ligament. An in vitro study performed with a new experimental technique. J Bone Joint Surg Am 72:4 557-567.

25. Howell, SM, Papadopoulos, S, Kuznik, KT, Hull, ML. 2013. Accurate alignment and high function after kinematically aligned TKA performed with generic instruments. Knee Surg Sports Traumatol Arthrosc 21:10 2271-2280.

26. Merican, AM, Ghosh, KM, Deehan, DJ, Amis, AA. 2009. The transpatellar approach for the knee in the laboratory. J Orthop Res 27:3 330-334.

27. Paschos, NK, Howell, SM, Johnson, JM, Mahfouz, MR. 2017. Can kinematic tibial templates assist the surgeon locating the flexion and extension plane of the knee? Knee 24:5 1006-1015.

28. Ward, SR, Eng, CM, Smallwood, LH, Lieber, RL. 2009. Are current measurements of lower extremity muscle architecture accurate? Clin Orthop Relat Res 467:4 1074-1082.

29. Churchill, DL, Incavo, SJ, Johnson, CC, Beynnon, BD. 2001. The influence of femoral rollback on patellofemoral contact loads in total knee arthroplasty. J Arthroplasty 16:7 909-918.

30. Ghosh, KM, Blain, AP, Longstaff, L, et al. 2014. Can we define envelope of laxity during navigated knee arthroplasty? Knee Surg Sports Traumatol Arthrosc 22:8 1736-1743.

31. Hunt, NC, Ghosh, KM, Blain, AP, et al. 2014. How does laxity after single radius total knee arthroplasty compare with the native knee? J Orthop Res 32:9 1208-1213.

32. Kwak, SD, Ahmad, CS, Gardner, TR, et al. 2000. Hamstrings and iliotibial band forces affect knee kinematics and contact pattern. J Orthop Res 18:1 101-108.

33. Li, G, Rudy, TW, Sakane, M, et al. 1999. The importance of quadriceps and hamstring muscle loading on knee kinematics and in-situ forces in the ACL. J Biomech 32:4 395-400.

34. Stoddard, JE, Deehan, DJ, Bull, AM, et al. 2013. The kinematics and stability of single-radius versus multi-radius femoral components related to mid-range instability after TKA. J Orthop Res 31:1 53-58.

35. Victor, J, Labey, L, Wong, P, et al. 2010. The influence of muscle load on tibiofemoral knee kinematics. J Orthop Res 28:4 419-428. 
medRxiv preprint doi: https://doi.org/10.1101/19013755; this version posted December 5, 2019. The copyright holder for this preprint (which was not certified by peer review) is the author/funder, who has granted medRxiv a license to display the preprint in perpetuity.

It is made available under a CC-BY-NC-ND 4.0 International license .

450
36. Wang, X, Malik, A, Bartel, DL, et al. 2014. Asymmetric varus and valgus stability of the anatomic cadaver knee and the load sharing between collateral ligaments and bearing surfaces. J Biomech Eng 136:8.

37. Bach, JM, Hull, ML, Patterson, HA. 1997. Direct measurement of strain in the posterolateral bundle of the anterior cruciate ligament. J Biomech 30:3 281-283.

38. Blankevoort, L, Huiskes, R, de Lange, A. 1988. The envelope of passive knee joint motion. J Biomech 21:9 705-720.

39. Markolf, KL, Mensch, JS, Amstutz, HC. 1976. Stiffness and laxity of the knee--The contributions of the supporting structures. J Bone Joint Surg Am 58-A:5 583-594.

40. Eagar, P, Hull, ML, Howell, SM. 2001. A method for quantifying the anterior load-displacement behavior of the human knee in both the low and high stiffness regions. J Biomech 34:12 1655-1660.

41. Mayman, D, Plaskos, C, Kendoff, D, et al. 2009. Ligament tension in the ACL-deficient knee: assessment of medial and lateral gaps. Clin Orthop Relat Res 467:6 1621-1628.

42. Heesterbeek, PJC, Verdonschot, N, Wymenga, AB. 2008. In vivo knee laxity in flexion and extension: A radiographic study in 30 older healthy subjects. Knee 15:1 45-49.

43. Witkovsky, V. 2014. On the exact two-sided tolerance intervals for univariate normal distribution and linear regression. Austrian J Stat 43:4 279-292.

44. LaPrade, RF, Bollom, TS, Wentorf, FA, et al. 2005. Mechanical properties of the posterolateral structures of the knee. Am J Sports Med 33:9 1386-1391.

45. Robinson, JR, Bull, AM, Amis, AA. 2005. Structural properties of the medial collateral ligament complex of the human knee. J Biomech 38:5 1067-1074.

46. Race, A, Amis, AA. 1994. The mechanical properties of the two bundles of the human posterior cruciate ligament. J Biomech 27:1 13-24. 


\section{Supplement 1: Illustrative example of difficulty with using mean sensitivities to guide balancing KA TKA}

To appreciate the difficulty with using the mean sensitivities to guide corrections in all knees, consider an illustrative case in which the surgeon measures a medial tibial force of $300 \mathrm{~N}$ and a lateral tibial force of $65 \mathrm{~N}$ in extension. Because the ideal tibial forces for a particular patient are unknown, it is reasonable to strive to achieve tibial forces comparable to the average in the native knee ${ }^{13}$, which are similar to those measured in calipered kinematically aligned TKA in vitro ${ }^{20}$. Using the mean tibial forces of the native knee as a target $(114 \mathrm{~N}$ in the medial compartment and $63 \mathrm{~N}$ in the lateral compartment $^{13}$ ), the medial force is $186 \mathrm{~N}$ too high, and the lateral force is $2 \mathrm{~N}$ too high, which indicates that there is a valgus malalignment of the tibial component (Figure 2, Table 1). Thus, a varus re-cut should correct the valgus malalignment and reduce the medial tibial force with minimal changes to the lateral tibial force (Figure 2, Table 1). However, the appropriate size of the varus re-cut remains to be determined.

To understand the importance of considering knee-to-knee variability in the sensitivities of the tibial forces, first assume that this patient has sensitivities equal to the highest determined in the present study (213 N/deg valgus malalignment, specimen 1, Table 3). If the surgeon used the average sensitivity to determine the appropriate re-cut, then a varus re-cut of $1.6^{\circ}$ would be performed (186 N / $\left.(118 \mathrm{~N} / \mathrm{deg})=1.6^{\circ}\right)$. However, in this high-sensitivity knee, a $1.6^{\circ}$ varus re-cut would be much too large because the actual decrease in the medial force would be $336 \mathrm{~N}$. Because a decrease of $336 \mathrm{~N}$ would be greater than the measured medial force, this re-cut would likely slacken the soft tissue restraints in the medial compartment, which might cause excessive laxity post-operatively. Next, assume that this patient has sensitivities equal to the lowest in the present study $(35 \mathrm{~N} / \mathrm{deg}$ valgus malalignment, specimen 7 , Table 3 ). In this low-sensitivity knee, the $1.6^{\circ}$ varus re-cut would be too 509 small because the actual decrease in medial tibial force would only be $56 \mathrm{~N}$. In both these patients, 510 additional surgical steps would be necessary to achieve tibial forces comparable to those of the native 511 knee, which is undesirable due to increasing time and complexity of the procedure. 